\title{
Case Report on Anti-Tubercular Drug Induced Hepatoxicity / Modified ATT
}

\author{
M Saru Khan ${ }^{1, *}$, Basil Sunny ${ }^{2}$, Rithuvaren M Krishnan ${ }^{3}$ \\ ${ }^{1}$ Department of Pharmacy Practice, Annai JKK Sampoorani Ammal College of Pharmacy, Erirmedu, Namakkal, Tamil Nadu, INDIA. \\ ${ }^{2}$ Manager and Clinical Pharmacologist of Sun Rise Hospital, Kochi, Kerala, INDIA. \\ ${ }^{3}$ Annai JKK Sampoorani Ammal College of Pharmacy, Tamil Nadu, INDIA.
}

\begin{abstract}
This case summary focusing on a 67-year male patient admitted in Sun rise Hospital, Kochi with $\mathrm{k} / \mathrm{c} / \mathrm{o}$ active tubercular on cat.2 ATT, now patient came complaint with c/o decreased appetite, food intake, nausea, vomiting and excessive fatigability. The patient was received first line anti tubercular drugs 6 months back RHZE (Rifampin, Pyrazinamide, Ethambutol, and Isoniazid) and discontinued medication 2 months back. Now it is developed a severe hepatitis which is an adverse drug reaction of the Antitubercular drugs.

Keywords: Hepatitis, Adverse drug reaction of anti-TB drug, Treatment, Pulmonary Koch infection, ALT, AST, Modified att.
\end{abstract}

\section{INTRODUCTION}

Tuberculosis is a potentially serious infectious bacterial disease that primarily affects the lungs. Many people infected with the bacteria that cause tuberculosis do not have symptoms. When symptoms occur usually like cough (sometimes bloodtinged), weight loss, night sweats and fever. ${ }^{1}$

Non-adherence to an anti-TB drug treatment was also significantly associated with drug side effects from medications that included continuing chemotherapy regimen, pill use, inadequate routine to visit clinical check-up and communication with health professionals, and lack of family support. ${ }^{2}$ TB disease can be treated by taking medication for several period of time up to $6-9$ months its depends upon severity of tuberculosis. There are 10 drugs which are currently approved by the U.S. Food and Drug Administration (FDA) for treating TB. The approved drugs, the firstline anti-TB agents that form the core of treatment regimens are: Isoniazid (INH), Rifampin (RIF), Ethambutol (EMB), and Pyrazinamide (PZA). ${ }^{3}$
According to the WHO, one-third of the population is affected by TB and 1 in 4 adult males is the cause of death. First line anti-TB drugs are potentially hepatotoxic. From first-line anti-TB drugs, isoniazid (INH), rifampin (RIF), and pyrazinamide (PZA) cause hepatotoxicity such as 2 transaminases and fulminant hepatitis failure. The incidence rate of anti-TB induced hepatotoxicity is found to range from $2 \%$ to $28 \%$, depending on the hepatotoxitis diagnosis criteria. ${ }^{4}$

Modified ATT is changing the drug regimen for hepatotoxicity in TB patient for the controlling serology values of ALT/AST by altering the previous treatment for TB.

\section{CASE REPORT}

A 67-year-old patient a known case of active tuberculosis on Cat II ATT, now came with $\mathrm{C} / \mathrm{O}$ decreased appetite, $\mathrm{C} / \mathrm{O}$ decreased food intake, $\mathrm{C} / \mathrm{O}$ nausea /vomiting, $\mathrm{C} / \mathrm{O}$ excessive fatigability. Past medical history of the patient is K/C/O TB 6 months back and the patient is discontinued medication 2 months back. Social history of the patients
DOI: 10.5530/ijopp.14.4.59

Address for correspondence: Mr. M Saru Khan,

Department of Pharmacy Practice, Annai JKK Sampoorani Ammal College of Pharmacy, Erirmedu, Namakkal, Tamil Nadu, INDIA. Phone no: +919042213293 Email id: Sarukhan007.M@ gmail.com

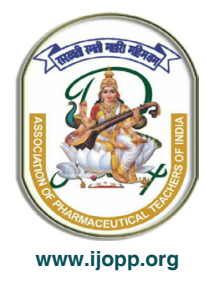


30 years of severe alcoholic and smoker. Physician suggest a chest CT SCAN finding an OLD PT HRCT THORAX Irregular cavities in right upper and lower lobes Centrilobular nodules in both lungs collapse with bronchiectasis in right middle lobe small (R) para tracheal PULMONORY KOCH'S INFECTION. ECG report shows Excessive overload of left atrium sinus tachycardia and ULTRASOUND SCAN finds a Bladder out flow obstruction.

\section{LABORATORY INVESTIGATION}

\section{DRUG CHART}

\section{TREATMENT PROGRESSION}

Day 1-6: Drugs given were antibiotics, hepatoprotective agents, laxatives and single anti tubercular drug for reducing chief complaints: appetite, nausea and fatigue. Reducing the level of BILIRUBIN, DIRECT AND INDIRECT BILIRUBIN, S.G.O.T/AST and S.G.P.T/ ALT.

Day 3-4: Trimeg sachet, mucolytic agent and GIT protective agent since pt. suffered from severe cough, ulceration and to reduce the bilirubin level.

Day 4-6: Tamusulosin, acetoaminophen, vit.b12 complex and alprazolam for relaxing the smooth muscle in bladder and prostrate for urine flow, antipyretic, improving HB level and to improve sleep/ reduce anxiety.

Day 7-12: Antibiotics, Anti tubercular agent and Hepatoprotective agents for treament for severe

\begin{tabular}{|c|c|c|c|c|}
\hline $\begin{array}{c}\text { Name of the } \\
\text { test }\end{array}$ & Day 2 & Day 5 & Day 11 & $\begin{array}{c}\text { Normal } \\
\text { range }\end{array}$ \\
\hline $\begin{array}{l}\text { Serum } \\
\text { Bilirubin }\end{array}$ & $4.4 \mathrm{mg} / \mathrm{dl}$ & $3.9 \mathrm{mg} / \mathrm{dl}$ & $2.3 \mathrm{mg} / \mathrm{dl}$ & $0.2-1 \mathrm{mg} / \mathrm{dl}$ \\
\hline $\begin{array}{c}\text { Direct } \\
\text { Bilirubin }\end{array}$ & $1.7 \mathrm{mg} / \mathrm{dl}$ & $1.0 \mathrm{mg} / \mathrm{dl}$ & $1.1 \mathrm{mg} / \mathrm{dl}$ & $0-0.2 \mathrm{mg} / \mathrm{dl}$ \\
\hline $\begin{array}{l}\text { Indirect } \\
\text { Bilirubin }\end{array}$ & $2.7 \mathrm{mg} / \mathrm{dl}$ & $2.9 \mathrm{mg} / \mathrm{dl}$ & $1.2 \mathrm{mg} / \mathrm{dl}$ & $\begin{array}{c}0.3-1.0 \\
\mathrm{mg} / \mathrm{dl}\end{array}$ \\
\hline $\begin{array}{l}\text { SR. Total } \\
\text { Protein }\end{array}$ & $5.3 \mathrm{~g} / \mathrm{dl}$ & $6.5 \mathrm{~g} / \mathrm{dl}$ & $6.0 \mathrm{~g} / \mathrm{dl}$ & $6-8 \mathrm{~g} / \mathrm{dl}$ \\
\hline Albumin & $2.4 \mathrm{~g} / \mathrm{dl}$ & $2.7 \mathrm{~g} / \mathrm{dl}$ & $2.4 \mathrm{~g} / \mathrm{dl}$ & $\begin{array}{c}3.4-5.4 \\
\mathrm{~g} / \mathrm{dl}\end{array}$ \\
\hline Globulin & $2.9 \mathrm{~g} / \mathrm{dl}$ & $3.8 \mathrm{~g} / \mathrm{dl}$ & $3.6 \mathrm{~g} / \mathrm{dl}$ & $2-3.5 \mathrm{~g} / \mathrm{dl}$ \\
\hline S.G.O.T IAST & 177 IU/L & $66 \mathrm{IU} / \mathrm{L}$ & $22 \mathrm{IU} / \mathrm{L}$ & 4-17 IU/L \\
\hline S.G.P.T /ALT & 155 IU/L & $59 \mathrm{IU} / \mathrm{L}$ & $21 \mathrm{IU} / \mathrm{I}$ & 3-5IU/L \\
\hline $\begin{array}{c}\text { Alkaline } \\
\text { Phosphatase }\end{array}$ & 103 IU/L & 102 IU/L & $81 \mathrm{IU} / \mathrm{L}$ & $\begin{array}{c}44-147 \\
\text { IU/L }\end{array}$ \\
\hline
\end{tabular}

tuberculosis to the patient and reducing the bilirubin range.

Justification for Therapy stop Isoniazid, Rifampin and Pyrizinamide for cause Hepatotoxicity to the patient and follow the therapy for 2 weeks.

\section{PHARMACIST INTERVENTION}

Drug Drug Interaction: All drugs are given rational and no interaction is found.

Discharge Medication: T.Levomar $750 \mathrm{mg}$ OD, T.Mycobutol 1000mg OD, T.Fourts B 10mg HS, T.Raliz L 20mg OD, Syp.Citralka 10ml BD.

Review after 15 days.

\section{DISCUSSION}

The incidence rate of drug induced hepatotoxicity in India is $8-36 \%$. The higher incidence of DIH was found in the Asian countries which may be due to ethnic susceptibility, inherent peculiarity of drug metabolism and/or the presence of various known risk factors such as $\mathrm{HBV}$ infection, malnutrition, and alcoholism. ${ }^{4}$ There causes of hepatotoxicity in patient in different countries varies between $1 \%$ and $10 \%$, depending on factors such as race, socio-economic conditions and geographical location. The occurrence of drug induced hepatitis is highest in India (8-10\%), possibly due to malnutrition, endemic viral hepatitis, alcoholism and genetic factors. ${ }^{5}$ Drug Induced Liver Injury (DILI) affected accounts about $7 \%$ of reported drug adverse effects, $2 \%$ of hospitalized jaundice, and approximately 30\% of fulminant liver injury. DILI has replaced viralhepatitis as the most apparent cause of acute liver failureA brief search of the commercial pharmacopoeia database reveals that there are over 700 drugs with reported hepatotoxicity and are approved for use in the United States. The US Food and Drug Administration (FDA), which has a background rate of 1 in 1,000,000 cases of idiopathic liver failure, has withdrawn the drug and forced it to exceed 1 in 50,000 individuals for serious or fatal liver injury. ${ }^{6}$

WHO has recommended at least five drugs in the intensive phase of treatment, defined by the use of a second-line injectable agent. The recent WHO change to recommending at least four effective drugs at initiation of treatment is graded as a conditional recommendation with very low certainty in the estimates of effect. Of note, both our guideline committee and the 2019 WHO guidelines promote the use of newer or repurposed oral 
Treatment Chart.

\begin{tabular}{|c|c|c|c|c|c|c|c|c|c|c|c|}
\hline S.No & Drug Name & Dose & $\begin{array}{l}\text { 㞻 } \\
\underset{\sim \alpha}{\sim}\end{array}$ & 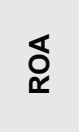 & 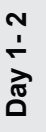 & $\stackrel{m}{\text { बิ }}$ & $\stackrel{+}{\text { สิ }}$ & ๙ & $\stackrel{0}{\stackrel{0}{\Delta}}$ & $\stackrel{\wedge}{\text { ते }}$ & 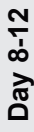 \\
\hline 1 & Inj. Cefoperazone \& sulbactam & $2 \mathrm{gm}$ & IV & $\mathrm{BD}$ & & & & & & $x$ & $x$ \\
\hline 2 & Inj. Pantoprazole & $40 \mathrm{mg}$ & IV & OD & & & & & & $x$ & $x$ \\
\hline 3 & T. Silymarin & $500 \mathrm{mg}$ & $\mathrm{P} / \mathrm{O}$ & TDS & & & & & & $x$ & $x$ \\
\hline 4 & T. Ursodeoxycholic acid & $300 \mathrm{mg}$ & $\mathrm{P} / \mathrm{O}$ & BD & & & & & & $x$ & $x$ \\
\hline 5 & T. Rifaximin & $550 \mathrm{mg}$ & $\mathrm{P} / \mathrm{O}$ & OD & & & & & & $x$ & $x$ \\
\hline 6 & Syp. Lactulose & $15 \mathrm{ml}$ & $\mathrm{P} / \mathrm{O}$ & OD & & & & & & $x$ & $x$ \\
\hline 7 & Trimethyl glycine granules & $3.5 \mathrm{gm}$ & $\mathrm{P} / \mathrm{O}$ & OD & $\mathrm{X}$ & & & & & $x$ & $x$ \\
\hline 8 & Syp. Sucralfate & $15 \mathrm{ml}$ & $\mathrm{P} / \mathrm{O}$ & TDS & $\mathrm{X}$ & & & & & $x$ & $x$ \\
\hline 9 & T. Acetylcysteine & $600 \mathrm{mg}$ & $\mathrm{P} / \mathrm{O}$ & BD & $\mathrm{X}$ & & & & & $x$ & $x$ \\
\hline 10 & T. Alprazolam & $0.25 \mathrm{mg}$ & $\mathrm{P} / \mathrm{O}$ & HS & $\mathrm{X}$ & $x$ & & & & $x$ & $x$ \\
\hline 11 & T. Mecobalamin & $1500 \mathrm{mcg}$ & $\mathrm{P} / \mathrm{O}$ & BD & $\mathrm{X}$ & $x$ & $x$ & & & $x$ & $x$ \\
\hline 12 & T. Acetaminophen & $650 \mathrm{mg}$ & $\mathrm{P} / \mathrm{O}$ & TDS & $\mathrm{x}$ & $x$ & $x$ & & & $x$ & $x$ \\
\hline 13 & C. Tamsulosin & $0.4 \mathrm{mg}$ & $\mathrm{P} / \mathrm{O}$ & OD & $\mathrm{X}$ & $x$ & & & & $x$ & $x$ \\
\hline 14 & Inj. Levofloxacin & $500 \mathrm{mg}$ & IV & OD & $\mathrm{X}$ & $x$ & $x$ & $x$ & $\mathrm{x}$ & & \\
\hline 15 & Inj. Amoxicillin clavuanate & $1.2 \mathrm{gm}$ & IV & BD & $\mathrm{X}$ & $x$ & $x$ & $x$ & $\mathrm{x}$ & & \\
\hline 16 & Inj. Streptomycin & $1 \mathrm{~g}$ & IM & OD & $\mathrm{X}$ & $x$ & $x$ & $x$ & $\mathrm{x}$ & & \\
\hline 17 & T. Ethambutol & $800 \mathrm{mg}$ & $\mathrm{P} / \mathrm{O}$ & OD & $\mathrm{x}$ & $x$ & $x$ & $x$ & $x$ & & \\
\hline 18 & T. Phenozopyridine & $100 \mathrm{mg}$ & $\mathrm{P} / \mathrm{O}$ & BD & $\mathrm{X}$ & $x$ & $x$ & $x$ & $\mathrm{X}$ & $x$ & \\
\hline 19 & Syp. Disodium hydrogen citrate & $1.53 \mathrm{gm} / 5 \mathrm{ml}$ & $\mathrm{P} / \mathrm{O}$ & BD & $\mathrm{X}$ & $x$ & $x$ & $x$ & $x$ & $x$ & \\
\hline
\end{tabular}

agents with greater efficacy and deemphasize the use of injectable agents. Given these changes and that an injectable drug is no longer obligatory, the intensive phase can no longer be defined by the inclusion of injectables. ${ }^{7}$

New Recommendations from the World Health Organization (2019) The new WHO recommendations are a departure from previous approaches to treat MDR-TB/RR-TB in several regards:Levofloxacin or moxifloxacin may be used. Consider high-dose isoniazid if inhA mutation. Levofloxacin is the recommended fluoroquinolone based on its safety profile and fewer drug-drug interactions. ${ }^{8}$ In the fast acetylators more than $90 \%$ of the drug is excreted into acetyl-isononiazide, whereas in the slow acetylating agent, $67 \%$ of the drug is excreted in the acetyl-isoniazide and produced in the urine as a drug with greater level of unchanged proportions of isoniazid. The effect of acetylation rate on isoniazid hepatotoxicity is controversial.

Rate of INH acetylation allows a genetic variation. There are

Fast acetylators (30-40\% of Indians)t1/2 of INH $1 \mathrm{hr}$.

Slow acetylators (60-70\% of Indians) t1/2 of INH $3 \mathrm{hr}$.
The proportion of fast and slow acetylators differs in different parts of the world. However, acetylator status does not matter if INH is taken daily, but biweekly regimens are less effective in fast acetylators. Isoniazid induced peripheral neuritis appears to be more common in slow acetylators. ${ }^{9}$

Why there are some patient only developing hepatotoxicity is not clear. Several studies suggest that have searched for host factors, environmental factors or genetic factors such as HLA typing, cytochrome P450 2E120 or acetylator status. ${ }^{10}$

\section{PATIENT EDUCATION}

As the role of the clinical pharmacist in providing advice on the drug to improve the patient's therapeutic adherence, follow the visits for monitoring and the symptoms of hepatotoxicity with appropriate reminders where possible. In the event of symptoms attributable to hepatotoxicity, patients should be advised to stop all anti-TB drugs and to consult a doctor in case of symptoms of hepatotoxicity and to consult a doctor immediately. To advise A report from an INH-based chemoprophylaxis program suggested that regular investigation and reporting of symptoms during Indian Journal of Pharmacy Practice, Vol 14, Issue 4, Oct-Dec, 2021 
monthly visits have proven effective in avoiding severe DILI without the need for routine liver biochemistry measurements. since these could potentially increase the toxicity leading to DILI. ${ }^{11}$

\section{CONCLUSION}

Patient developed hepatoxicity due to adverse effect of first line treatment of anti-TB drug and patient are severe alcoholic capdable of developing of hepatits. The patient were diagnosed PULMONARY KOCH'S INFECTION, were standard treatment are providing to the patient to reduced the level of ALT/AST. we are able to achieving the clinical improvement and outcomes of the patient.

\section{ACKNOWLEDGEMENT}

To take this oppurtunity to thanks to Dr. Basil Sunny, pharm.D, Clinical Pharmacologist, Sunrise Hospital, Cochin, for providing continous support and valuable guidelines.

\section{CONFLICT OF INTEREST}

The authors declare no conflict of interest.

\section{ABBREVIATIONS}

DILI: Drug induced liver injury; ATT: Anti tubercular treatment; ALT: Alanine aminotransferase; AST: Asparate Aminotransferase; INH: Isoniazid; TB: Tuberculosis.

\section{REFERENCES}

1. Tuberculosis - Symptoms and causes [internet]. Mayo Clinic Publications; 2021 [cited Apr 19 2021]. Available from: https://www.mayoclinic.org/diseasesconditions/tuberculosis/symptoms-causes/syc-20351250.

2. Tesfahuneygn G, Medhin G, Legesse M. Adherence to Anti-tuberculosis treatment and treatment outcomes among tuberculosis patients in Alamata District, northeast Ethiopia. BMC Res Notes. 2015;8(1):503. doi: 10.1186/ s13104-015-1452-x, PMID 26420164.

3. Center for Global Health stories of hope sorted by date [internet]; 2021. CDC. gov [cited Apr 19 2021]. Available from: https://www.cdc.gov/globalhealth/ stories/date-list.html.

4. KA, AM, S.AA, KN, SI, MM. Anti-tuberculosis drug - induced hepatitis - A case report [internet]; 2021. ljopp.org. [cited Apr 19 2021] Available from: http://www. ijopp.org/article/194.

5. Tost JR, Vidal R, Caylà J, Díaz-Cabanela D, Jiménez A, Broquetas JM, Study Group for Severe Hepatotoxicity due to Anti-tuberculosis Drugs and the Study Group for Severe Hepatotoxicity. Severe hepatotoxicity due to anti-tuberculosis drugs in Spain. Int J Tuberc Lung Dis. 2005;9(5):534-40. PMID 15875925.

6. Saukkonen JJ, Cohn DL, Jasmer RM, Schenker S, Jereb JA, Nolan CM, Peloquin CA, Gordin FM, Nunes D, Strader DB, Bernardo J, Venkataramanan R, Sterling TR, ATS (American Thoracic Society) Hepatotoxicity of Antituberculosis Therapy Subcommittee. An official ATS statement: hepatotoxicity of antituberculosis therapy. Am J Respir Crit Care Med. 2006;174(8):935-52. doi: 10.1164/rccm.200510-1666ST, PMID 17021358.

7. Nahid P, Mase SR, Migliori GB, Sotgiu G, Bothamley GH, Brozek JL, Cattamanchi A, Cegielski JP, Chen L, Daley CL, Dalton TL, Duarte R, Fregonese F, Horsburgh CR, Ahmad Khan F, Kheir F, Lan Z, Lardizabal A, Lauzardo M, Mangan JM, Marks SM, McKenna L, Menzies D, Mitnick CD, Nilsen DM, Parvez F, Peloquin CA, Raftery A, Schaaf HS, Shah NS, Starke JR, Wilson JW, Wortham JM, Chorba T, Seaworth B. Treatment of drug-resistant tuberculosis. An official ATS/CDC/ERS/IDSA clinical practice guideline. Am JRespirCrit Care Med. 2019;200(10):e93-e142. doi: 10.1164/rccm.201909-1874ST, PMID 31729908.

8. $\mathrm{R}$ mase $\mathrm{s}$, Chorba T. Treatment of drug-resistant tuberculosis. ELSEVIER [internet]. p. 775-95; 2019 [cited Jul 8 2021];40(4). Available from: https://www. sciencedirect.com/science/article/abs/pii/S0272523119300668?via\%3Dihub.

9. TRIPATHI KD. Antimicrobial drugs. In: TRIPATHI KD, editor. Essentials of MEDICAL PHARMACOLOGY. 7th ed. New Delhi: JAYPEE; 2013.

10. Singla R, Sharma SK, Mohan A, Makharia G, Sreenivas V, Jha B, Kumar S, Sarda Pawan, Singh S. Evaluation of risk factors for antituberculosis treatment induced hepatotoxicity. PubMed 2010 Jul;132:81-6.

11. Nolan C, Goldberg S, Buskin S. Hepatotoxicity Associated with Isoniazid Preventive Therapy. JAMA. 1999;281(11):1014. 